\title{
Impacts of late Quaternary fluctuations in water level on the accumulation of sedimentary organic matter in Walker Lake, Nevada
}

\author{
Philip A. Meyers \\ Department of Geological Sciences and Center for Great Lakes and Aquatic Studies, The University of Michigan, \\ Ann Arbor, MI 48109-1063 (U.S.A.)
}

(Received 1 August, 1989; accepted 13 October 1989)

\begin{abstract}
Meyers, P. A., 1990. Impacts of late Quaternary fluctuations in water level on the accumulation of sedimentary organic matter in Walker Lake, Nevada. Palaeogeogr., Palaeoclimatol., Palaeoecol., 78: 229-240.

Walker Lake, a terminal saline lake in western Nevada, has experienced major fluctuations in its water level due to changes in regional climate and river diversions during the late Quaternary. Change in the degree of preservation of sediment organic matter has accompanied the lake level fluctuations, and changes in the biotic sources of organic matter to the lake sediments have occurred in response to the climate changes and water diversions. The record of these events has been studied using organic matter $\mathrm{C} / \mathrm{N}$ ratios and carbon isotope contents and employing molecular compositions of geolipids extracted from the sediment. Modern sediments contain mostly lake-derived organic matter which has been altered by microbial reworking. Decreases in the degree of preservation of organic matter indicate lake lowstands. Increases in the proportion of land-plant components in sediment organic matter also indicate lowstand conditions.
\end{abstract}

\section{Introduction}

Organic matter in lake sediments represents the residue remaining after the degradation and alteration of aquatic and watershed biota. Local environments control the relative proportions of contributing biota and hence influence the production and also the preservation of organic matter. Changes in paleolimnological and paleoclimatic conditions are thereby recorded in the overall character of organic matter in sediments deposited at different times.

Different types of biota produce organic matter which can be distinguished on the bases of molecular, elemental, and isotopic compositions. Organic matter produced by aquatic biota is composed largely of proteinaceous, carbohydrate, and lipid materials. Vascular land plants contains these types of materials, plus large contributions of lignin and cellulose from woody tissues. During its transport and deposition, organic matter commonly experiences substantial microbial reworking, with the result that much of the proteinaceous and carbohydrate material is destroyed. Because of this reworking, considerable alterations of the original character of organic matter occur. Components less susceptible to destruction, however, survive, and they preserve evidence of past biota and living conditions in lacustrine environments.

Geolipid compositions have been widely employed to make paleoenvironmental comparisons of subaqueous sediments deposited at different times and in different settings. For example, Brooks et al. $(1976,1977)$ studied fatty acid and hydrocarbon distributions in modern sediments from three English lakes and from three coastal marine locations. Different environments yielded different distributional patterns. Similarly, Meyers and Takeuchi (1979) compared the fatty acid and 
hydrocarbon distribution of various sedimentary environments in Lake Huron. They concluded that sediment texture and distance from land influence the compositions of these geolipid fractions. Organic matter inputs over multi-thousand-year periods of depositional history have been characterized using distributions of fatty acids, alkanes, and sterols in sediments of Mono Lake (Reed, 1977), of Cam Loch (Cranwell, 1977), and of Heart Lake (Meyers et al., 1984). Based upon studies of geolipid compositions of sediments from oligotrophic and eutrophic lakes (Cranwell, 1978, 1981; Cranwell and Volkman, 1981), it appears that the trophic status of lakes is important to both the types of material incorporated into sediments and the extent of organic matter preservation. Fatty acids, in particular, seem to be especially sensitive indicators of changes in preservational conditions (Meyers et al., 1980a, b; Kawamura and Ishiwatari, 1984; Kawamura et al., 1987).

Carbon isotope compositions of organic matter have not been widely used in studies of lake sediments, yet the limited data indicate the paleoenvironmental information which may be provided by organic matter isotope records. Krishnamurthy et al. (1986) present data from a 2.4 m.y. core of sediment from Pleistocene Lake Karewa, India. Concordant shifts in isotope and $\mathrm{C} / \mathrm{N}$ ratios appear to record episodes of lake desiccation during glacial periods. Ishiwatari and Uzaki (1987) compare organic carbon isotope and lignin contents of Lake Biwa sediments deposited over the past 600 k.y. A systematic shift from isotope ratios of -28 in older sediments to $-26 \%$ in modern sediments is postulated to indicate a warming trend. Sackett et al. (1986) report a shift in carbon isotope values from -27 to $-24 \%$ in a core of Lake Ontario sediment which corresponds to deforestation of the watershed in the mid-1800s and replacement of $\mathrm{C} 3$ native plants by $\mathrm{C4}$ agricultural plants.

As part of the broad study of paleoclimatology of the Walker Lake region, we have investigated the carbon isotopic and geolipid molecular distributions, as well as the total organic carbon contents, of sediments deposited at various intervals over the past $150 \mathrm{k} . \mathrm{y}$. of lake history.

\section{Walker Lake}

Walker Lake is a terminal lake in the Great Basin region of western Nevada (Fig.1). Its water levels have varied markedly in response to natural climatic changes. Major demands for agricultural water since the early 1900 s have substantially lowered the lake level. Benson (1978) reconstructs the history of this lake and its pluvial ancestor, Lake Lahontan, over the past 40,000 years, and Cooper and Koch (1984) describe the modern lake and its biota. The lake waters are presently alkaline, having a pH of 9.4 and a salinity of about 10 parts per thousand. Mid-summer blooms of the blue-green alga Nodularia spumigena dominate the aquatic production of organic matter. Land areas around the lake are dry and are vegetated by typical plants of the Basin and Range Desert, predominantly sagebrush, saltbrush, and rabbitbrush, except along the Walker River, where cottonwood and willow line the riverbanks. At higher elevations, juniper and pinyon pine grow.

\section{Samples}

Samples of Walker Lake sediment were obtained from two types of sampling operations during 1984. Drilling near the center of the lake provided samples recording the depositional history. Cores 4 and 5 were drilled from essentially the same location in $37 \mathrm{~m}$ water depth (Fig.1) to give an overlapping and thus more complete record. Two transects across the lake gave Ekman grab samples of modern sediments (Fig. 1). These provide a measure of the type of organic matter accumulating in the identifiable depositional conditions of today and thus form a basis from which to infer past depositional environments.

To obtain more information about the character of modern inputs of organic matter to the sediments of this lake, samples of biota from around and in the lake were collected. Vegetation was sampled from the surrounding land and from the banks of the Walker River. Samples of mixed plankton and of the blue-green alga Nodularia were obtained from the lake waters.

Samples intended for analysis of their geolipid 


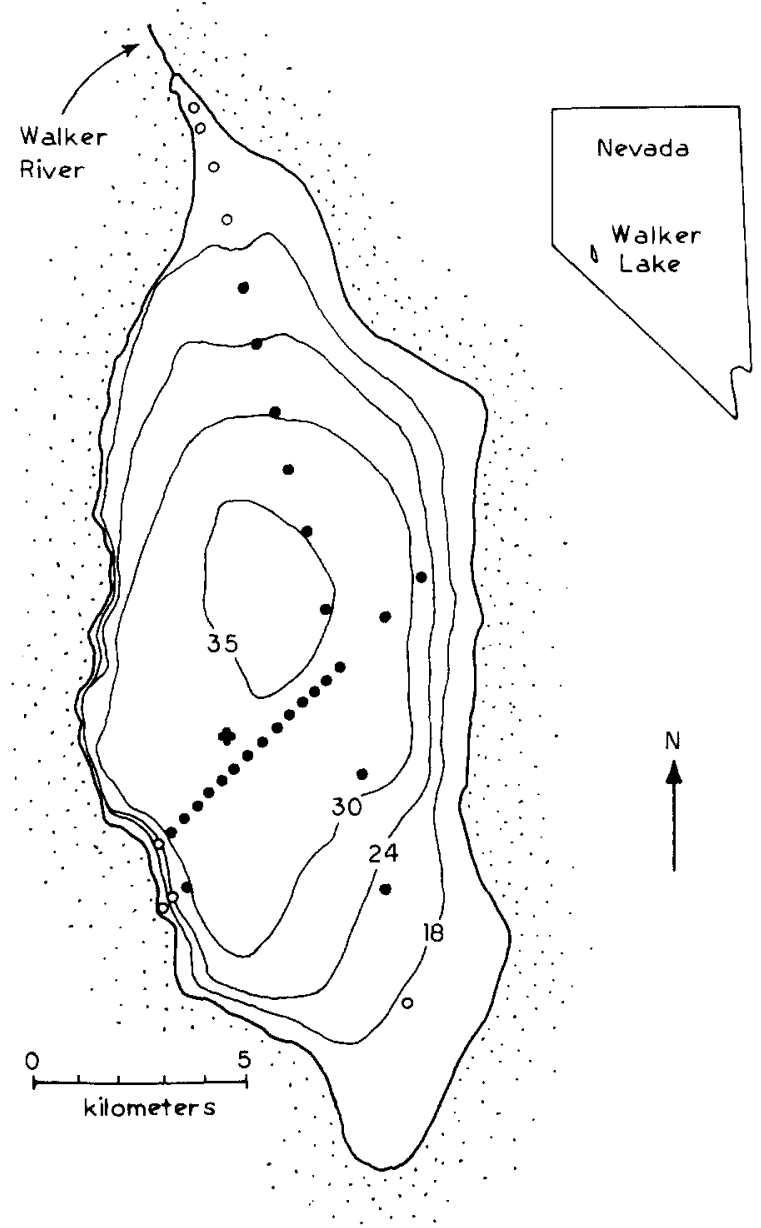

Fig.1. Sampling stations in Walker Lake, Nevada, July 1984. Circles represent Ekman grab locations: solid circles, $20 \mathrm{~m}$ or deeper; open circles, $20 \mathrm{~m}$ or shallower. Cross shows the location of drilled cores 4 and 5. Depth contours are in meters below the 1984 water level.

contents, which can be attacked and altered by microbes, were frozen upon collection and kept frozen until analyses began. Samples for which only isotopic and elemental analyses of bulk organic matter were planned were refrigerated but not frozen until they reached The University of Michigan. All samples were freeze-dried as the first step in their analyses.

\section{Analysis}

Calcium carbonate contents were determined by the carbonate bomb technique (Müller and Gast- ner, 1971). Residual carbon was measured with a Hewlett-Packard 185B CHN Analyzer after $\mathrm{HCl}$ dissolution of carbonates and was considered to represent the total organic carbon content. Organic matter atomic $\mathrm{C} / \mathrm{N}$ ratios were determined from residual carbon values. Organic carbon concentrations of the samples were calculated on a dry-weight basis for the original, carbonate-containing sediment.

Stable carbon isotope ratios of the organic carbon content of these samples were determined on carbonate-free samples using a VG Micromass 602 mass spectrometer calibrated with NBS-20 (carbonate) and NBS-21 (graphite) standards. Data are corrected for ${ }^{17} \mathrm{O}$ and are presented relative to the PDB standard.

Geolipids were released from samples of freezedried sediment by Soxhlet extraction with toluene/ methanol for $24 \mathrm{~h}$. After being concentrated, the extracts were saponified and treated with methanolic boron trifluoride as described by Leenheer (1981). Internal standards of C-36 n-alkane and of methyl heptadecanoate were added to each subsample. Column chromatography of each sample on a column packed with aluminum oxide over silica gel as detailed by Leenheer (1981) provided four fractions: hydrocarbons (saturated plus aromatic), fatty acid methyl esters, a sterol-alcohol fraction, and a column wash. The components of the sterol/alcohol fractions were converted to their silyl ethers with bis(trimethylsilyl)trifluoroacetamide, and an internal standard of 5 A-cholestane was added to these fractions for quantification by gas chromatography.

Hydrocarbon, fatty acid methyl ester, and fatty alcohol ether fractions of sediment lipids were analyzed using a Hewlett-Packard 5830A FID gas chromatograph equipped with a $20 \mathrm{~m} \mathrm{SE}-54$ capillary column and fitted with an on-column injection system. Hydrogen was used as the carrier gas and nitrogen as the makeup gas. Quantitative results were obtained using the internal standard amounts after corrections were made with response factors calculated from standard mixes. The reported results have been further corrected for small amounts of laboratory contamination as determined from blank analyses. 


\section{Results and discussion}

\section{Modern biota}

The samples of watershed and lake biota were analyzed for their elemental and carbon isotopic contents (Table 1). $\mathrm{C} / \mathrm{N}$ ratios are obviously higher in the cellulose-containing land plants than in the non-cellulosic algae of the lake. Differences in isotopic ratios are evident between $\mathrm{C} 3$ and $\mathrm{C} 4$ plants, but there are no clear isotopic distinctions between aquatic and land plants in this survey. The two aquatic samples may be slightly depleted in ${ }^{13} \mathrm{C}$ relative to land plants as a result of the cooler temperature of the lake water relative to the surrounding desert area, where summer maximum temperatures average $38^{\circ} \mathrm{C}$ (Cooper and Koch, 1984). Alternatively, this depletion may be a consequence of the isotopic ratio of the dissolved carbonate in the lake.

The difference in isotopic compositions of the $\mathrm{C} 3$ and $\mathrm{C} 4$ plants has potentially important implications to tracing paleoenvironmental change in the Walker Lake region. As noted by Dorn and DeNiro (1985), increases in aridity evidently create shifts towards smaller fractions of $\mathrm{C} 3$ plants in the total land vegetation of North American deserts. They found organic matter isotope ratios in rock varnish to reflect these shifts. If land-derived organic matter is a significant part of the total sediment organic matter, then the sediment isotope record should show any changes in proportions of C3 and C4 plants due to climate changes. Alternatively, if lake-derived organic matter is dominant, then any decrease in the domination of halophilic Nodularia due to freshening of the lake waters would result in a relative productivity shift towards $\mathrm{C} 3$ phytoplankton and a concomitant shift to lighter isotope values.

\section{Surface sediment transects}

The results of the elemental and isotopic analyses of the transect samples are listed in Table 2, along with the approximate water depths at each transect station. The $\mathrm{C} / \mathrm{N}$ values average 8.3 and have a relatively small range. These values are typical of organic material produced by algal
TABLE 1

Elemental and isotopic ratios of modern biota from Walker Lake and its watershed

\begin{tabular}{|c|c|c|}
\hline Sample & $\mathrm{C} / \mathrm{N}$ & $\delta^{13} \mathrm{C}$ \\
\hline \multicolumn{3}{|l|}{ Deciduous trees (C3) } \\
\hline willow & 38 & -26.7 \\
\hline cottonwood & 22 & -25.0 \\
\hline aspen & 102 & -25.8 \\
\hline poplar & 62 & -27.9 \\
\hline \multicolumn{3}{|l|}{ Coniferous trees (C3) } \\
\hline juniper & 47 & -22.5 \\
\hline pinyon pine & 42 & -24.8 \\
\hline \multicolumn{3}{|l|}{ Shrubs (C3) } \\
\hline big sage & 38 & -26.4 \\
\hline rabbitbrush & 57 & -25.2 \\
\hline Mormon tea & 39 & -23.4 \\
\hline mountain mahogany & 30 & -23.1 \\
\hline greasewood & nd & -23.5 \\
\hline \multicolumn{3}{|l|}{ Shrubs (C4) } \\
\hline tumbleweed & 68 & -12.5 \\
\hline salt grass & 160 & -14.1 \\
\hline saltbrush & nd & -12.9 \\
\hline green molly & nd & -13.3 \\
\hline \multicolumn{3}{|l|}{ Lake biota } \\
\hline Nodularia spumigena $(\mathrm{C} 4)$ & 13 & -18.6 \\
\hline mixed plankton (C3) & 8 & -28.8 \\
\hline
\end{tabular}

nd: not determined.

or bacterial synthesis (Müller, 1977; Bourbonniere, 1979; Meyers et al., 1984a) and hence suggest a predominance of aquatic organic matter in sediments recently deposited throughout Walker Lake. The mean $\delta^{13} \mathrm{C}$ value is $-24.2 \%$, and these values, like the $C / N$ ratios, show little variation. The carbon isotope ratios do not clearly define the predominant source of sediment organic matter, yet they suggest possible sources. A mixture of organic carbon equally derived from Nodularia and from plankton would give an isotopic ratio of $-23.7 \%$, very close to the mean value of surface sediments. In Walker Lake, however, Nodularia constitutes the bulk of the primary producers and contributes well over half of the production of organic matter (Cooper and Koch, 1984). Because a Nodularia-dominated source of organic carbon would yield an isotopic value less depleted in ${ }^{13} \mathrm{C}$ than is found in the surficial sediments, organic matter produced by this alga either degrades more 
TABLE 2

Elemental and isotopic character of organic matter from Ekman grab samples of Walker Lake sediment, 1984

\begin{tabular}{|c|c|c|c|c|c|}
\hline Station & $\begin{array}{l}\text { Water depth } \\
\text { (m) }\end{array}$ & $\begin{array}{l}\mathrm{CaCO}_{3} \\
(\%)\end{array}$ & $\begin{array}{l}\mathrm{C}_{\text {org }} \\
(\%)\end{array}$ & $\begin{array}{l}\text { Atomic } \\
\mathrm{C} / \mathrm{N}\end{array}$ & $\delta^{13} \mathrm{C}_{\text {org }}$ \\
\hline WLS-84-1 & 14 & 8.4 & 0.48 & 8.62 & -25.81 \\
\hline WLS-84-2 & 21 & 12.1 & 1.11 & 8.42 & -26.81 \\
\hline WLS-84-3 & 32 & 20.5 & 3.08 & 8.39 & -24.49 \\
\hline WLS-84-4 & 36 & 19.1 & 3.13 & 8.21 & -24.60 \\
\hline WLS-84-5 & 36 & 21.4 & 3.22 & 7.68 & -24.58 \\
\hline WLS-84-6 & 20 & 8.3 & 1.04 & 9.11 & -23.34 \\
\hline WLS-84-7 & 35 & 22.9 & 1.81 & 8.16 & -25.42 \\
\hline WLS-84-8 & 36 & 19.9 & 3.59 & 8.02 & -24.31 \\
\hline WLS-84-9 & 36 & 21.9 & 3.27 & 8.04 & -24.43 \\
\hline WLS-84-10 & 36 & 21.2 & 3.48 & 7.90 & -24.03 \\
\hline WLS-84-11 & 36 & 22.5 & 3.25 & 7.97 & -24.46 \\
\hline WLS-84-12 & 36 & 21.5 & 3.66 & 7.51 & -23.92 \\
\hline WLS-84-13 & 36 & 20.0 & 3.73 & 7.87 & -24.37 \\
\hline WLS-84-14 & 36 & 22.4 & 3.83 & 7.99 & -24.39 \\
\hline WLS-84-15 & 36 & 22.1 & 3.98 & 7.87 & -24.48 \\
\hline WLS-84-16 & 36 & 20.4 & 3.98 & 7.92 & -23.89 \\
\hline WLS-84-17 & 36 & 21.7 & 3.59 & 7.64 & -24.06 \\
\hline WLS-84-18 & 36 & 20.0 & 3.39 & 7.93 & -24.30 \\
\hline WLS-84-19 & 36 & 21.7 & 3.09 & 7.88 & -24.38 \\
\hline WLS-84-20 & 33 & 16.7 & 3.45 & 7.23 & -22.85 \\
\hline WLS-84-21 & 23 & 21.3 & 3.27 & 7.88 & - \\
\hline WLS-84-22 & 15 & 26.3 & 1.70 & 7.65 & -23.46 \\
\hline WLS-84-25 & 27 & 20.1 & 1.67 & 8.85 & -23.51 \\
\hline WLS-84-26 & 34 & 21.9 & 3.35 & 8.12 & - \\
\hline WLS-84-27 & 19 & 9.5 & 0.73 & 8.30 & -23.09 \\
\hline WLS-84-28 & 1 & 6.6 & 0.63 & 11.62 & - \\
\hline WLS-84-29 & 5 & 7.4 & 0.85 & 9.36 & - \\
\hline WLS-84-30 & 13 & 7.0 & 0.90 & 9.79 & -23.27 \\
\hline WLS-84-31 & 18 & 16.0 & 2.01 & 8.42 & -23.46 \\
\hline WLS-84-32 & 24 & 17.4 & 3.03 & 8.51 & -23.84 \\
\hline WLS-84-33 & 28 & 17.3 & 3.01 & 7.93 & -23.60 \\
\hline WLS-84-34 & 33 & 19.0 & 4.02 & 8.05 & - \\
\hline WLS-84-35 & 35 & 21.7 & 3.37 & 8.18 & -24.27 \\
\hline WLS-84-36 & 35 & 22.9 & 3.26 & 8.38 & -24.35 \\
\hline WLS-84-37 & 37 & 21.3 & 4.48 & 8.91 & -24.72 \\
\hline \multicolumn{2}{|l|}{ Low value } & 6.6 & 0.48 & 7.51 & -22.85 \\
\hline \multicolumn{2}{|l|}{ High value } & 26.3 & 4.48 & 11.62 & -25.81 \\
\hline \multicolumn{2}{|l|}{ Mean value } & 18.3 & 2.76 & 8.31 & -24.22 \\
\hline \multicolumn{2}{|c|}{ Stand deviation } & 5.4 & 1.16 & 0.79 & 0.81 \\
\hline
\end{tabular}

quickly in the waters of Walker Lake than does that of other alga, or the Nodularia blooms give a false picture of the amount of annual productivity contributed by this plant. The possibility that a blend of mostly land $\mathrm{C} 3$ input, which averages $-24.9 \%$ from Table 1, and traces of Nodularia and land $\mathrm{C} 4$ inputs may make up the organic matter in modern sediments of Walker Lake can be discarded from the $\mathrm{C} / \mathrm{N}$ value, which is too low for organic matter from cellulosic land plants.

In contrast to the $\mathrm{C} / \mathrm{N}$ and $\delta^{13} \mathrm{C}$ values, the percentages of calcium carbonate and organic carbon change considerably among the transect samples. Comparison of these data with the depths of the transect stations (Meyers and Benson, 1988) indicates that both percentages are lower for shallower sediments and become greater at deeper locations. Although changes in mass accumulation rates can affect concentrations of both carbonate minerals and organic matter in lake sediments by increasing or decreasing their times of exposure to dissolution and degradation, respectively (Rea et al., 1980), it is probable that depth-influenced hydraulic sorting of sediment particle sizes is more important than sedimentation rates to create the carbon trends present in modern sediments of Walker Lake. The shallower sediments are coarser and are more likely to contain clastic, noncarbonate material. Coarse sediments commonly have lower concentrations of organic carbon than do fine-sized lake deposits (e.g. Meyers and Takeuchi, 1979). Because deeper parts of the lake bottom experience less water turbulence, their sediments will be finer in size and more likely to contain lake-derived biogenic carbonates.

Although these water-depth-related changes in calcium carbonate and organic carbon concentrations await further study for their definite explanation, their presence offers a potential measure of relative water depth when sediments deposited at different periods at one location in Walker Lake are compared. Depth estimates obtained in this way are at best crude, and they must be considered provisional until the reasons for the depth correlations are definitively explained.

\section{Sediment samples from cores 4 and 5}

Sediment samples from Cores 4 and 5 provide the record of past depositional conditions in the Walker Lake basin. The deepest core sample is from $147.5 \mathrm{~m}$ sub-bottom and from radiometric dating is estimated to be around 375,000 years old (Benson, 1988). Seventy core samples were analyzed for calcium carbonate, organic carbon, $\mathrm{C} / \mathrm{N}$ ratios and $\delta^{13} \mathrm{C}$ values. The down-core variation 
patterns of concentrations of calcium carbonate and of organic carbon share many similarities, as shown in Fig.2. Decreases in both calcium carbonate and organic carbon occur over the upper $20 \mathrm{~m}$ of sediments, then values increase somewhat deeper in the sediments. In general, organic matter concentrations are lower throughout the deeper sections of the core than near its upper part, although enhanced concentrations are found around $63 \mathrm{~m}$ and $83 \mathrm{~m}$ sub-bottom.

Based upon the correlation between concentrations of carbonate and of organic carbon seen in the transect data, the variations in the downcore concentrations may result from changes in lake water level (Meyers and Benson, 1988). If sediments containing $10 \%$ or less calcium carbonate and $1 \%$ or less organic carbon are considered representative of shallow water depositional condi-

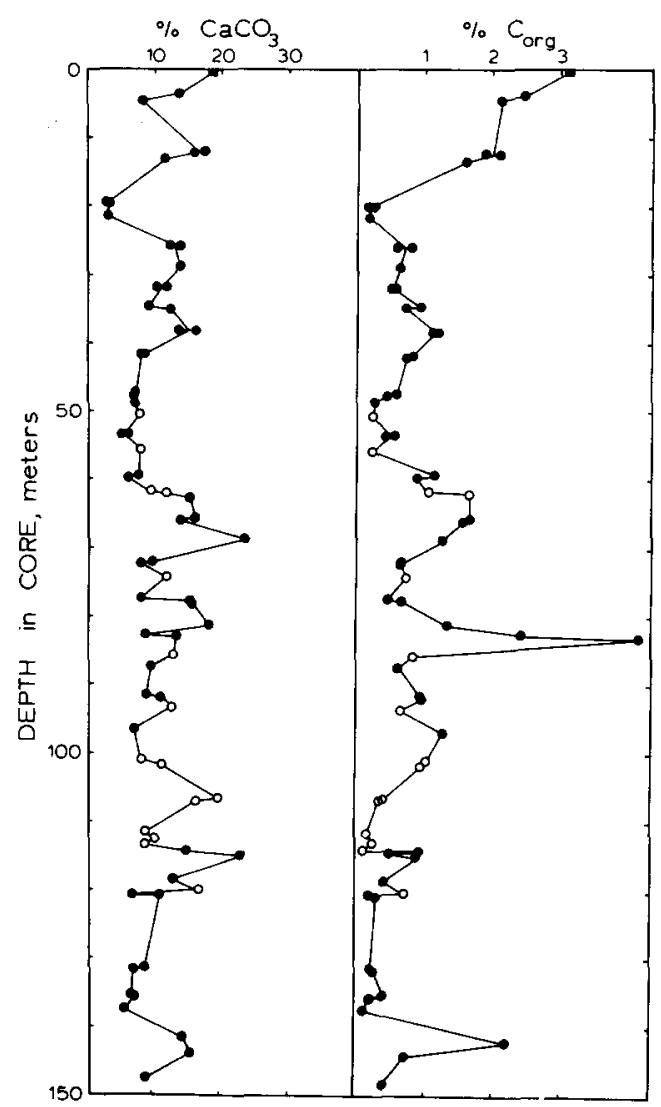

Fig.2. Percentages of calcium carbonate and of organic carbon in drilled core samples from Walker Lake. Solid symbols represent Core 4; open symbols are data from Core 5. tions, then five periods of possible lowered lake level can be found from the patterns in Fig. 2. These periods correspond to sub-bottom depths of 20-22 m, 48-56 m, 72-78 m, 110-113 m, and 131-138 $\mathrm{m}$. The most strongly developed of these five possible events is around $20 \mathrm{~m}$, and the time of this event is estimated to be between 13,000 to 9000 years before present (Benson, 1988).

Although they have similar downcore patterns, carbonate and organic matter concentrations do not correlate statistically well with each other. The probable reason for the poor correlation is the sensitivity of organic matter to a number of changing parameters - inputs from land and aquatic biosynthesis, sinking times within the water, burial rates in the lake bottom, dilution by mineral material, dissolution of carbonates which affect its concentration. The general decline in organic matter concentrations seen as sediment depth increases in the core suggests continued postburial destruction of organic matter, although at rates slowed by the absence of oxygen dissolved in pore waters of deeper sediment. Variations in the degree of this degradation can contribute to deviations from the carbonate pattern.

Comparison of the downcore values of $\mathrm{C} / \mathrm{N}$ ratios and $\delta^{13} \mathrm{C}$ values of samples from cores 4 and 5 shows considerable variation but no systematic correlation in these two possible identifiers of organic matter sources (Fig.3). If changes in the relative proportions of land vs lake contributions of organic matter are the dominant reasons for variations in $\delta^{13} \mathrm{C}$ and $\mathrm{C} / \mathrm{N}$ values, then correlations should exist. Samples dominated by organic matter derived from Nodularia should have $\delta^{13} \mathrm{C}$ values in the range of -18 to $-20 \%$ and $C / N$ ratios around 13; those in which $\mathrm{C} 3$ land plant organic matter dominates would have isotope values of -22 to $-28 \%$ and $C / N$ ratios above 20 . If, on the other hand, lake-derived organic matter has dominated the input to sediments over the $150 \mathrm{Ky}$ period represented by these cores, then $\mathrm{C} / \mathrm{N}$ values should consistently remain low but $\delta^{13} \mathrm{C}$ ratios can range between the $-18 \%$ of Nodularia to the $-28 \%$ value of the plankton (Table 1). Variable preservation of organic matter will complicate identification of the original character of the organic constituents of lake sediments deposited 


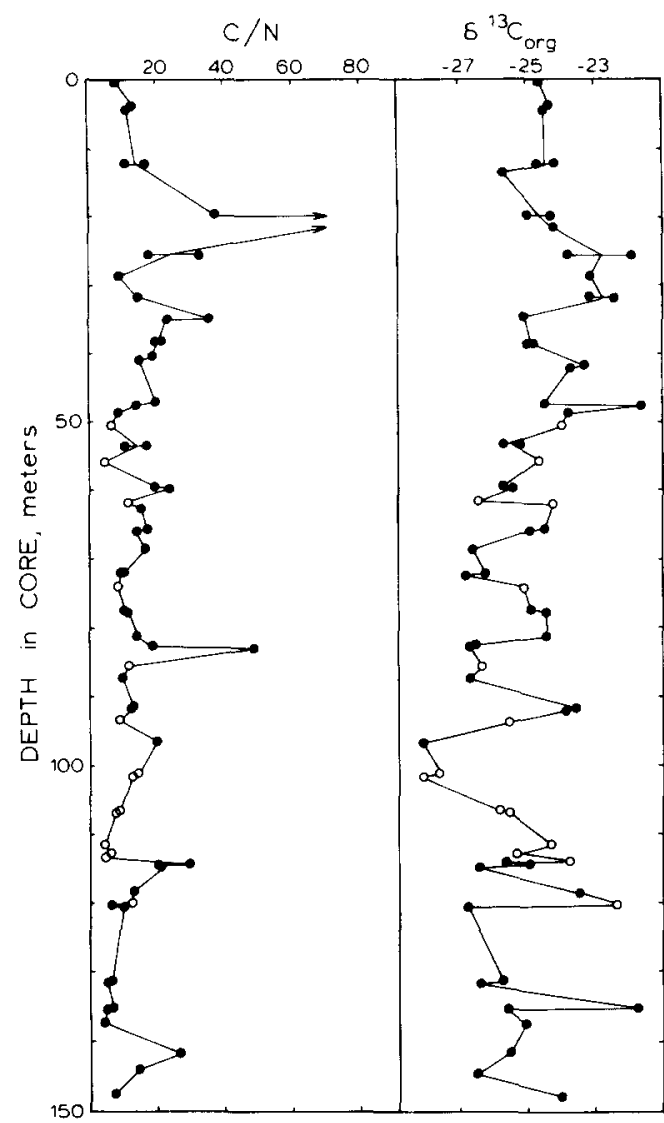

Fig.3. Atomic $\mathrm{C} / \mathrm{N}$ ratios and $\delta^{13} \mathrm{C}$ values for organic matter from drilled core samples from Walker Lake. Core 4 values are represented by solid symbols; Core 5 data are given by open symbols.

at different times, but discernible evidence should remain.

Aithough data from lacustrine sediments are limited, $\delta^{13} \mathrm{C}$ values of sediment organic matter appear to provide an accurate record of the original source material (e.g. Sackett et al., 1986; Ishiwatari and Uzaki, 1987). In organic-carbonrich marine sediments, diagenetic shifts of up to $5 \%$ towards heavier values have been observed (e.g. Benner et al., 1987), yet in more typical coastal sediments both $\delta^{13} \mathrm{C}$ and $\mathrm{C} / \mathrm{N}$ give good records of organic matter sources (e.g. Jasper and Gagosian, 1989). It is probable that the isotope ratios in Walker Lake sediments provide a reasonable history of organic matter inputs. Modern sediments $\left(\delta^{13} \mathrm{C}\right.$ of about $-24 \%, \mathrm{C} / \mathrm{N}$ of about 8 , Table 2) contain mostly aquatic organic matter. A predominantly aquatic source of modern sediment organic matter is further indicated by a strongly aliphatic character from ${ }^{13} \mathrm{C}$ NMR analyses of sediment humic substances isolated from core 4 samples (P. Hatcher, pers. comm., 1990) and from surface sediments (Domagalski et al., 1989).

$\mathrm{C} / \mathrm{N}$ values in the core samples are somewhat higher than those of modern samples, although they are generally significantly lower than those of land plants (Table 1). These elemental ratios do not fully agree with the source character as indicated by carbon isotopes. This disagreement probably results mostly from poorer preservation of nitrogenous components of non-modern organic matter in the sediments. Such components are more reactive, hence more degradable, than are most other constituents of biological matter. Selective loss of nitrogenous compounds results in diagenetically enhanced $\mathrm{C} / \mathrm{N}$ ratios in sediment organic matter. $\mathrm{C} / \mathrm{N}$ ratios in the $40-60$ range might also record short periods of predominantly C3 land-plant inputs of organic matter to the lake sediments. The best example of such a possibility is at $84 \mathrm{~m}$ sub-bottom, where $\mathrm{C} / \mathrm{N}=49$ and $\mathrm{W}^{13} \mathrm{C}=-26.6 \%$. Dramatic shifts of $\mathrm{C} / \mathrm{N}$ ratios from their original values can occur if sediments are heated, causing loss of both organic and inorganic forms of nitrogen and raising $\mathrm{C} / \mathrm{N}$ values (e.g. Simoneit et al., 1984). The absence of nitrogen in sediments from 19 to $22 \mathrm{~m}$ sub-bottom in Walker Lake (Fig.3) may indicate solar heating of the lake bottom during desiccation of Walker Lake between 13 and 9 k.y. ago.

Based on the $\mathrm{C} / \mathrm{N}$ data, aquatic materials have dominated the contributions of organic matter to the sediments of Walker Lake over the history represented by Cores 4 and 5 (Fig.3). Isotopic variations, therefore, must record shifts in the relative importance of inputs from the blue-green alga Nodularia and the other phytoplankton, mostly diatoms (Cooper and Koch, 1984), living in the lake. According to information cited by Cooper and Koch (1984), Nodularia has an optimal growth range at salinities between 5 and 20 parts per thousand. Freshening of lake waters during times of higher lake stands may have decreased the productivity of this $\mathrm{C} 3$ alga, and the diminished contribution of organic matter from 
this now-dominant source would be recorded as a greater depletion of ${ }^{13} \mathrm{C}$ in the sediment. Possible examples of such shifts in inputs are common between $50 \mathrm{~m}$ and $105 \mathrm{~m}$ sub-bottom.

\section{Geolipid characteristics of cored sediments}

The extractable total lipid content of sediments, which will be called geolipids in this report, constitutes a small $(<3 \%)$ fraction of the total organic matter. Its molecular composition can nonetheless provide valuable information about organic carbon sources and preservation. In uniformly deposited lacustrine sediments, geolipid concentrations commonly decrease with depth as a result of continued postdepositional microbial reworking (Cranwell, 1977, 1978, 1981; Kawamura and Ishiwatari, 1984; Matsuda and Koyama, 1977; Meyers et al., 1980a; Nishimura, 1977). The concentrations of $n$-alkanes, $n$-alkanols, and $n$ alkanoic acids in these Walker Lake core samples, however, fluctuate with sediment depth (Meyers and Benson, 1988). Highest concentrations of some of the geolipid fractions occur deep in the core. A similar lack of an obvious relationship between geolipid concentrations and sediment depth has been observed in sediments of certain other lakes, for example in the record of the postglacial history of Heart Lake, New York (Meyers et al., 1984b). Patterns of this type evidently reflect non-uniform depositional conditions in which the rates of organic matter input and preservation vary. They probably also indicate changes over time in the composition of organic matter contributions to the sediments.

Concentrations of total $\mathrm{C}_{14}$ to $\mathrm{C}_{28} n$-alkanoic acids are an order of magnitude lower than are total $n$-alkanol concentrations in the cored sediments (Meyers and Benson, 1988), which is the converse of what is normally found in fresh biological matter. The loss of the dominance of the acids suggests substantial microbial reworking and consequent degradation of the sediment organic matter, during which the more easily degraded acids have been preferentially destroyed. Variations in the relative amounts of the geolipid fractions suggest that the degree to which this reworking has altered the original character of the organic matter has not been the same at all periods of sediment deposition. Fluctuations in lake level would be a major factor in such variability.

To identify where changes in sources and degree of preservation of sediment organic matter occurred, a partial assessment was made of the organic matter character using the proportion of geolipids to the total organic content. These ratios, presented in Fig.4, show that the contributions of total $n$-alkanes, $n$-alkanoic acids, and $n$-alkanols constitute small amounts indeed of the total organic carbon in the sediments of Walker Lake. They also illustrate that the proportions of the three classes of geolipids to the sedimentary organic matter vary with time of deposition. The variations in these proportions indicate where depositional conditions change in this sediment core.

Higher proportions of $n$-alkanes, a class of compounds which has a relatively low susceptibility to microbial degradation, indicate periods of time either when organic matter richer in lipid content was deposited or when bulk organic matter was subjected to greater amounts of degradation, thereby concentrating the hydrocarbons. Samples from $19,32,53$, and $147 \mathrm{~m}$ represent such periods. To help distinguish between the two possible reasons for enhanced $n$-alkane proportions, the contributions of the land-plant $\mathrm{C}_{27}, \mathrm{C}_{29}$, and $\mathrm{C}_{31}$ $n$-alkanes to the total organic carbon concentrations have been summed (Fig.4). The proportion of land-plant hydrocarbon waxes to total sediment organic carbon has been found to be an indicator of the relative amount of land-derived carbon in coastal marine sediments (Prahl and Carpenter, 1984; Prahl, 1985). Higher proportions of $n$ alkanoic acids and $n$-alkanols, which are relatively more degradable than are $n$-alkanes, may also record inputs of material richer in lipids, but are more likely to record periods of better preservation of organic matter. The proportions of land-plant $\mathrm{C}_{24}, \mathrm{C}_{26}$, and $\mathrm{C}_{28}$ components of these two geolipid classes to total organic carbon are also shown in Fig.4.

The importance of the land-plant contributions to the total concentrations of each of the three classes of geolipids is evident from the similarities in downcore patterns between the proportions of 


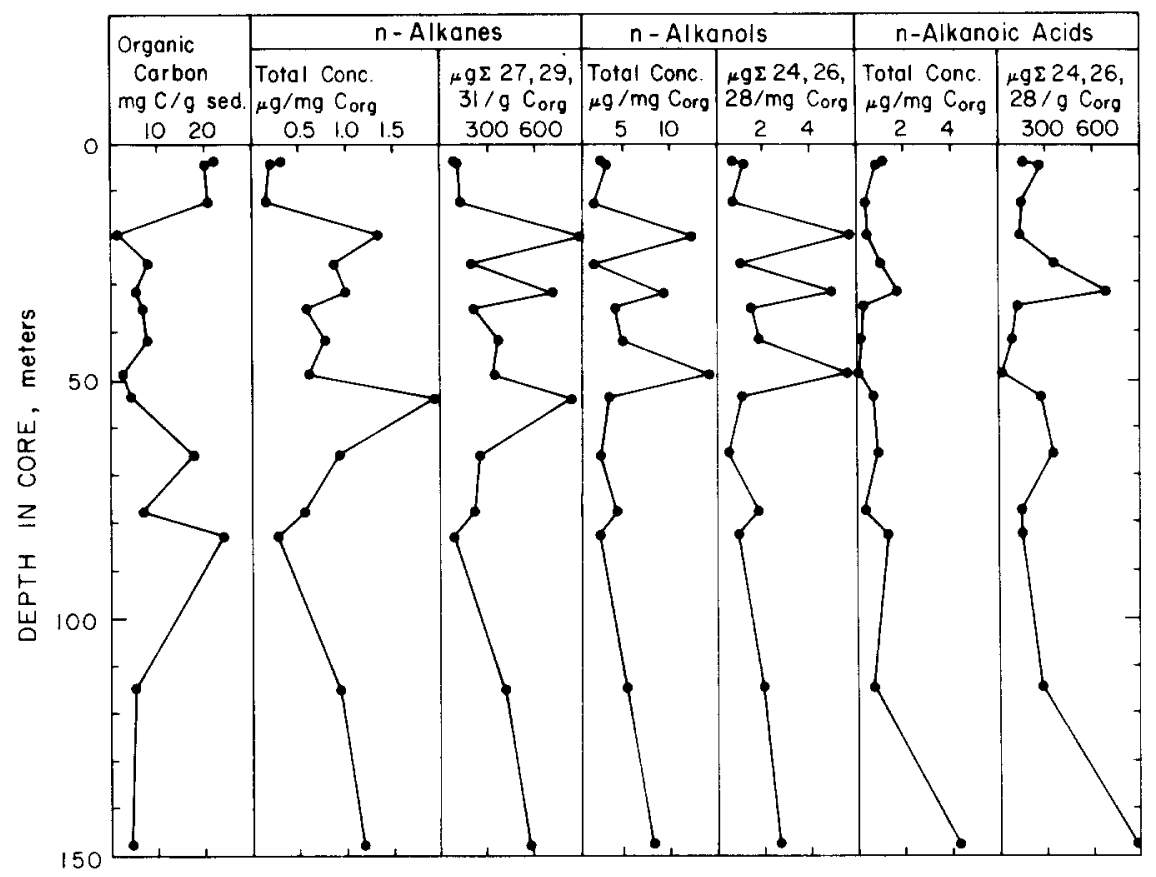

Fig.4. Concentrations of extracted total geolipid fractions and land-plant geolipid components from Walker Lake Core 4 normalized to organic carbon concentrations.

the total amounts and the sums of the long-chain components. The land-plant wax components constitute about half of the total $n$-alkane, $n$ alkanol, and $n$-alkanoic acid concentrations. As found in many sedimentary settings (e.g. Goossens et al., 1989), the wax lipids probably substantially over-represent the contribution of land plants to the total lipid matter of Walker Lake sediments. The geolipid contents of several core sections nonetheless provide information about paleodepositional conditions affecting the total organic matter.

The lowstand postulated to have occurred between 20 and $22 \mathrm{~m}$ sub-bottom from carbonate and organic carbon concentrations impacted the geolipid compositions. Concentrations of total $n$ alkanes and $n$-alkanols and of their land-plant wax components relative to organic carbon peak in the $20 \mathrm{~m}$ sample (Fig.4). Loss of more easily degraded forms of organic matter evidently enhanced the concentrations of these geolipids. The $n$-alkanoic acids, however, are relatively more degradable than are the other two geolipid classes. The acid concentrations are depressed, suggesting that subaerial conditions unfavorable to organic matter preservation may have existed at this time, estimated at 13-9 k.y. (Benson, 1988).

A second episode of greater-than-usual degradation of organic matter is recorded at $53 \mathrm{~m}$ subbottom. Although organic carbon concentrations are not particularly low, the very high amount of $n$ alkanes relative to the organic carbon suggest that degradation has enhanced the hydrocarbon proportion of the sediment organic matter. Both $n$ alkanols and $n$-alkanoic acids are low in relative concentrations at this depth, indicating that microbial reworking was extensive.

Evidence of a change in organic matter source is indicated by the occurrence at $32 \mathrm{~m}$ sub-bottom of peaks in concentrations of land-plant components of all three geolipid classes. The change in lipid character, combined with a relatively moderate concentration of organic carbon, suggests that sediments deposited at this time received organic matter enriched in land-derived lipid material. Porosity data presented by Benson (1988) indicate that Walker Lake was at low levels or dry for most of the interval from 23 to $37 \mathrm{~m}$ sub-bottom (23-14 k.y.). Carbon isotope ratios shift to heavier values in this interval (Fig.3), perhaps recording greater 
proportions of contributions of organic matter from $\mathrm{C} 4$ arid-climate land plants. The organic content of the sediment sample at $147 \mathrm{~m}$ subbottom is similar to that at $32 \mathrm{~m}$; this interval may have also received an enhanced amount of landplant lipid material. In both cases, the most likely source of such organic matter would be vegetation situated close to the core site, requiring desiccation of the lake bed.

Another type of change in organic matter source is indicated by the occurrence of a high concentration of lipid-poor organic matter at $82 \mathrm{~m}$ subbottom (Fig.4), which couples with a high $\mathrm{C} / \mathrm{N}$ value and a lighter carbon isotope content (Fig.3). These organic matter characteristics suggest a dominance of woody material, perhaps peat, at this sediment depth. Marshy conditions may have prevailed at this time.

The organic matter characteristics at $48 \mathrm{~m}$ subbottom evidently signal some sort of source or preservational change, but their interpretation remains elusive. Low concentrations of organic carbon and of the $n$-alkanoic acid proportion suggest extensive microbial reworking. Such reworking should produce an enhancement in $n$ alkane contents of the organic matter; this is not found. Instead, $n$-alkanol contents are elevated, but this geolipid class typically is lost to reworking before $n$-alkanes are affected. The change in lipid character may result not from reworking but rather from a modification of the sources of organic matter. Indeed, the $\mathrm{C} / \mathrm{N}$ value of 9 in this sediment section is lower than those in most other core samples, although the isotope ratio $(-23.8 \%$ ) is not exceptionally different. An enhanced input of some type of alkanol-rich aquatic organic matter may have occurred at this time. The nature of the source of this material and of the paleoenvironment it represents cannot be defined further from the existing geochemical information.

\section{Conclusions}

The conclusions inferred about Walker Lake from this study of the organic matter contents of surficial sediment from two transects and of the organic matter record of older sediment from a drilled core are:
(1) Modern sediments receive organic matter which is dominated by lake-sourced biota. A mixture of $\mathrm{C} 3$ phytoplankton and of $\mathrm{C} 4$ bluegreen algae provide the bulk of sediment organic matter. Land-plants contribute a small, but undetermined fraction of the total.

(2) Microbial reworking of sediment organic matter is widespread and alters the original character of this material. $\mathrm{C} / \mathrm{N}$ ratios typically become elevated as a consequence of this reworking, and in some samples residual hydrocarbon contents become enhanced as the more degradable fractions of organic matter are destroyed.

(3) Variations in the degree of organic matter preservation are found in sediments deposited at different times. Poorer preservation occurs when the core site was subaerially exposed during lowstands of the lake. The most dramatic example of this effect is at $20 \mathrm{~m}$ sub-bottom in the cored sediment.

(4) Changes in organic matter sources is evident at several core depths. Material enriched in landplant lipids is present at 32 and $147 \mathrm{~m}$ sub-bottom and may record dominance of arid climate vegetation. Material depleted in both aquatic and landplant lipids is found at $82 \mathrm{~m}$; this may indicate the former dominance of peat-forming marsh plants.

Interpretation of the organic matter compositions is constrained by the limited information available about the original character of the biological source material.

\section{Acknowledgements}

I thank L. V. Benson for providing the sediment samples and for sharing his information and insights of the Walker Lake system. K. C. Lohmann graciously provided the carbon isotope analyses and P. L. Dunham performed the organic matter analyses. This study was supported by a grant from the U.S. Department of the Interior, administered by the U.S. Geological Survey.

\section{References}

Benner, R., Fogel, M. L., Sprague, E. K. and Hodson, R. E., 1987. Depletion of ${ }^{13} \mathrm{C}$ in lignin and its implications for stable carbon isotope studies. Nature, 329: 708-710.

Benson, L. V., 1978. Fluctuation in the level of pluvial Lake 
Lahontan during the last 40,000 years. Quat. Res., 9: $300-318$.

Benson, L. V., 1988. Preliminary paleolimnologic data for the Walker Lake subbasin, California and Nevada. WaterResour. Invest. Rep., 87-4258, U.S. Geol. Surv., Denver. Colo., 50 pp.

Bourbonniere, R. A., 1979. Geochemistry of humic matter in Holocene Great Lakes sediments. Thesis. Univ. Michigan, 373 pp.

Brooks, P. W., Eglinton, G., Gaskell, S. J., McHugh, D. J., Maxwell, J. R. and Philp, R. P., 1976. Lipids of recent sediments, part I: straight-chain hydrocarbons and carboxylic acids of some temperate lacustrine and sub-tropical lagoonal/tidal flat sediments. Chem. Geol., 18: 21-38.

Brooks, P. W., Eglinton, G., Gaskell, S. J., McHugh, D. J., Maxwell, J. R. and Philp, R. P., 1977. Lipids of recent sediments, part II: Branched and cyclic alkanes and alkanoic acids of some temperate lacustrine and sub-tropical lagoonal/tidal-flat sediments. Chem. Geol, 20: 189-204.

Cooper, J. J. and Koch, D. L., 1984. Limnology of a desertic terminal lake, Walker Lake, Nevada, U.S.A. Hydrobiology, 118: 275-292.

Cranwell, P. A., 1977. Organic geochemistry of Cam Loch (Sutherland) sediments. Chem. Geol., 20: 205-221.

Cranwell, P. A., 1978. Extractable and bound lipid components in a freshwater sediment. Geochim. Cosmochim. Acta, 42: 1523-1532.

Cranwell, P. A., 1981. Diagenesis of free and bound lipids in terrestrial detritus deposited in a lacustrine sediment. Org. Geochem., 3: 79-89.

Cranwell, P. A., 1982. Lipids of aquatic sediments and sedimenting particles. Prog. Lipid Res., 21: 271-308.

Cranwell, P. A., 1984. Lipid geochemistry of sediments from Upton Broad, a small productive lake. Org. Geochem., 7: 25-37

Cranwell, P. A. and Volkman, J. K., 1981. Alkyl and steryl esters in a recent lacustrine sediment. Chem. Geol., 32: 29-43.

Domagalski, J. L., Orem, W. H. and Eugster, H. P., 1989. Organic geochemistry and brine composition in Great Salt, Mono, and Walker Lakes. Geochim. Cosmochim. Acta, 53: 2857-2872.

Dorn, R. I. and DeNiro, M. J., 1985. Stable carbon isotope ratios of rock varnish organic matter: $A$ new paleoenvironmental indicator. Science, 227: 1472-1774.

Drimmie, R. J., Fritz, P. and Kemp, A. W. L., 1974. Stable carbon isotopes in Lake Erie and Lake Ontario. Abstr. 17th Conf. on Great Lakes Res., p. 9.

Goossens, H., Duren, R. R., De Leeuw, J. W. and Schenck, P. A., 1989. Lipids and their mode of occurrence in bacteria and sediments. II. Lipids in the sediment of a stratified, freshwater lake. Org. Geochem., 14: 27-41.

Ishiwatari, R. and Uzaki, M., 1987. Diagenetic changes of lignin compounds in a more than 0.6 million-year-old lacustrine sediment (Lake Biwa, Japan). Geochim. Cosmochim. Acta, 51: 321-328.

Jasper, J. P. and Gagosian, R. B., 1989. Glacial-interglacial climatically-forced sources of sedimentary organic matter to the late Quaternary northern Gulf of Mexico. Nature, 342: 60-62.
Kawamura, K. and Ishiwatari, R., 1984. Fatty acid geochemistry of a $200 \mathrm{~m}$ sediment core from Lake Biwa, Japan. Early diagenesis and paleoenvironmental information. Geochim. Cosmochim. Acta, 48: 251-266.

Kawamura, K., Ishiwatari, R. and Ogura, K., 1987. Early diagenesis of organic matter in the water column and sediments: Microbial degradation and resynthesis of lipids in Lake Haruna. Org. Geochem., 11: 251-264.

Krishnamurthy, R. V., Bhattacharya, S. K. and Kusumgar, S., 1986. Paleoclimatic changes deduced from ${ }^{13} \mathrm{C} /{ }^{12} \mathrm{C}$ and $\mathrm{C} / \mathrm{N}$ ratios of Karewa lake sediments, India. Nature, 323: $150-152$

Leenheer, M. J., 1981. Use of lipids as indicators of diagenetic and source-related change in Holocene sediments. Thesis. Univ. Michigan, $246 \mathrm{pp}$.

Leenheer, M. J. and Meyers, P. A., 1983. Comparison of lipid compositions in marine and lacustrine sediments. In: $\mathbf{M}$. Bjoroy (Editor), Advances in Organic Geochemistry. Wiley, New York, N.Y., pp. 309-316.

Matsuda, H. and Koyama, T., 1977. Early diagenesis of fatty acids in lacustrine sediments. I. Identification and distribution of fatty acids in recent sediment from a freshwater lake. Geochim. Cosmochim. Acta, 41: 777-783.

Meyers, P. A. and Takeuchi, N., 1979. Fatty acids and hydrocarbons in surficial sediments of Lake Huron. Org. Geochem., 1: 127-138

Meyers, P. A. and Benson, L. V., 1988. Sedimentary biomarker and isotopic indicators of the paleoclimatic history of the Walker Lake basin, western Nevada. Org. Geochem., 13: 807-813.

Meyers, P. A., Bourbonniere, R. A. and Takeuchi, N., 1980a. Hydrocarbons and fatty acids in two cores of Lake Huron sediments. Geochim. Cosmochim. Acta, 44: 1215-1221.

Meyers, P. A., Maring, H. B. and Bourbonniere, R. A., 1980b. Alkane and alkanoic acid variations with depth in modern sediments of Pyramid Lake. In: A. G. Douglas and J Maxwell (Editors), Advances in Organic Geochemistry Pergamon, pp. 365-374.

Meyers, P. A., Leenheer, M. J., Eadie, B. J. and Maule, S. J., 1984a. Organic geochemistry of suspended and settling particulate matter in Lake Michigan. Geochim. Cosmochim. Acta, 48: 443-452

Meyers, P. A., Kawka, O. E. and Whitehead, D. R., 1984 b. Geolipid, pollen and diatom stratigraphy in postglacial lacustrine sediments. Org. Geochem., 6: 727-732.

Müller, G. and Gastner, M., 1971. The "karbonate bomb", a simple device for determination of the carbonate content in sediments, soils, and other materials. Neues. Jahrb. Mineral., 10: 446-469.

Peters, K. E., Sweeny, R. E. and Kaplan, I. R., 1978. Correlation of carbon and nitrogen stable isotope ratios in sedimentary organic matter. Limnol. Oceanogr., 23: 598-604.

Peterson, B. J., Howarth, R. W. and Garritt, R. H., 1985. Multiple stable isotopes used to trace the flow of organic matter in estuarine food webs. Science, 227: 1361-1363.

Prahl, F., 1985. Chemical evidence of differential particle dispersal in the southern Washington coastal environment. Geochim. Cosmochim. Acta, 49: 2533-2539.

Prahl, F. and Carpenter, R., 1984. Hydrocarbons in Washing- 
ton coastal sediments. Estuarine Coast. Shelf Sci., 18: 703-720.

Premuzic, E. T., Benkovitz, C. M., Gaffney, J. S. and Walsh, J. J., 1982. The nature and distribution of organic matter in the surface sediments of world oceans and seas. Org. Geochem., 4: 63-77.

Rea, D. K., Owen, R. M. and Meyers, P. A., 1981. Sedimentary processes in the Great Lakes. Rev. Geophys. Space Phys., 19: 635-648.

Reed, W. E., 1977. Biogeochemistry of Mono Lake, California. Geochim. Cosmochim. Acta, 41: 1231-1245.
Simoneit, B. R. T., Philp, R. P., Jenden, P. D. and Galimov, E. M., 1984. Organic geochemistry of Deep Sea Drilling Project sediments from the Gulf of California - Hydrothermal effects on unconsolidated diatom ooze. Org. Geochem., 7: 173-205.

Sackett, W. M., Eadie, B. J. and Meyers, P. A., 1986. Stable carbon isotope studies of organic matter in Great Lakes sediments. Trans. Am. Geophys. Union, 67: 1058 (abstract). Simoneit, B. R. T., 1986. Biomarker geochemistry of black shales from Cretaceous oceans - An overview. Mar. Geol., 70: 9-41. 